\title{
ARTIFICIAL NEURAL NETWORK FOR OPTIMIZATION OF THE DYNAMIC LINEAR MODEL OF PRODUCTION
}

\author{
ANNA LANDOWSKA \\ Faculty of Management and Economics of Services, University of Szczecin, Poland \\ e-mail: anna.landowska@wzieu.pl
}

\author{
\begin{tabular}{l|l} 
RECEIVED & 18 January 2018
\end{tabular} \\ ACCEPTED $\quad 2$ September 2018 \\ JEL \\ CLASSIFICATION \\ C45, C61, D24, E23
}

KEYWORDS

quality management, production management, artificial neural network, optimization, dynamic linear model

ABSTRACT

The article presents the usage of artificial neural network for optimization of the dynamic models of plants production. This approach for optimization is part of the production and quality management where it is very important to obtain a high-quality product. For production management many different models can be used. In the paper the differences between the staged production models were described. Also the characteristics of artificial neural network used to find solutions of the staged models were presented. Each dynamic model of plant production takes into account the crop rotation. The crop rotation is necessary to keep the soil in good condition and to obtain higher crops.

\section{Introduction}

Optimization process is very important in many areas of management, for example in: service management, production management, logistic management, finance management, information management, quality management, strategic management, risk management and many others. Presented in the paper optimization approach supports the production and quality management. The author presents concept of an artificial neural 
network (ANN) for optimization of production linear models with a dynamic character. The ANN was used to determine the coefficients of the objective function, which was agricultural income from crop production.

The four years of production model includes plant changes by combining subsequent production periods with several conditions. Proper crop rotation is important for the plant production process because it contributes to keep the soil in good condition resulting in higher yields. Lack of proper plant changes results in soil degradation which may cause plant diseases and lower quality crop.

In the paper three dynamic models of plant production: serial, serial-parallel and parallel are considered. These models in details are described in (Landowska, Landowski, 2012, pp. 48-50). Moreover, in (Landowska, Landowski, 2012, pp. 48-50, Landowska, 2017, p. 6) the schemes of three optimization models are presented.

The serial model has four stages, in each stage one production period is optimized. In this model the results obtained after each of the four optimization stages are included in the next optimization step. The serial-parallel model is a two-stage model where in the first stage the first and the second production period are optimized while in the second stage the third and fourth production period are optimized. It should be emphasized that each stage in the serial-parallel model takes into account the results of the optimization from the previous stage. The parallel model is a one-stage model. In this model, all periods are optimized simultaneously taking into account the conditions that connect all production periods. This approach to optimization makes models dynamic in accordance with the Bellman principle of optimality (Bellman, 1957, 2003). Optimization of the production process in agricultural farms using dynamic parallel models has been described by Zaród (2004, pp. 405-415; 2008, pp. 429-435; 2010, pp. 261-267) and Więckowski (1982). In these works, the authors describe model solutions taking into account many production periods related to conditions including plant changes.

Dynamic models are used in many agricultural problems. For example, the use of dynamic models for management of forest plantations can be found in Hartman (1976), Kennedy (1986), Cacho, Hean (2004). Li et al. in (2007) built a dynamic model for forecasting infection of pear leaves. The influence of changes of the frost intensity on Scottish pine was modeled with the dynamic model (Leinonen, 1996).

The main goal of the paper is to use artificial neural network (ANN) to optimize plant production and choose this production model (serial, serial-parallel, parallel) for which ANN gives the highest income.

\section{Characteristics of artificial neural network for production optimization}

Artificial neural network (ANN) is based on the natural neuron (nerve cell). ANN is a network whose nodes are neurons. Artificial neurons have inputs in which the input signal is multiplied by appropriate weights, then calculation operations are performed using appropriate mathematical functions. The modification of the input weights means that at the output we can receive the signal that we expect. One neural network can have many neurons and it is the most difficult to set the network so that we get the signal expected by us at the output. Many algorithms that deal with the selection of appropriate weight values for the input signal have been proposed. Neural network tuning is called network learning or training (Rutkowski, 2005, p. 170).

An artificial neural network for optimization of the linear models was proposed by Kopeć (2004, p. 198). On this basis an artificial neural network was built for optimization the dynamic plant production model. The task is to minimize the objective function $f$ :

$$
\min f(x)=\min C X=\min \sum_{i=1}^{n} c_{i} x_{i},
$$


with constraint conditions: $A X \leq B, x_{i} \geq 0$, where $A$ is $m \times n$ matrix, $B$ is a matrix of $m \times 1, X$ is $m \times 1$ matrix and $C$ is a matrix of $1 \times n$. To find the maximum value of the objective function, the optimization of the function $-f(x)$ is needed.

Based on (Kopeć, 2004, p. 195) we will use the penalty function as below:

$$
P(m)\left\{\begin{array}{lll}
=0 & \text { for } & m \leq 0 \\
>0 & \text { for } & m>0
\end{array}\right.
$$

Thus, the function that will be optimized will consist of the objective function and the part of determining penalty:

$$
E(x)=\sum_{i=1}^{n} c_{i} x_{i}+K \sum_{j=1}^{m} P_{j}\left(r_{j}(x)\right)
$$

where $r_{j}(x)=\sum_{i=1}^{n} a_{j i} x_{i}-b_{j}, K>0, i=1, \ldots, n ; j=1, \ldots, m ; m, n \in N$.

If the model constraints are satisfied then value of $r_{j}(x)$ is equal or less than zero, it means that the solution received is acceptable. Otherwise, $r_{j}(x)$ is greater than zero, which increases the value of the function $E(x)$.

For the penalty function $P(m)$, the signal $s_{1 j}^{k}$ in the neural network is as follows:

$$
s_{1 j}^{k}=\left\{\begin{array}{lll}
0 & \text { for } & r_{j}^{k}(x) \leq 0 \\
k & \text { for } & r_{j}^{k}(x)>0
\end{array} .\right.
$$

The signal at the output from the second layer of neurons equals:

$$
s_{2 i}^{k}=\sum_{j=1}^{m} a_{j i} s_{1 j}^{k}+c_{i} .
$$

The signal correction is made according to the following formula:

$$
s_{2 i}^{k}=s_{3 i}^{k-1}-\mu_{i} \times s_{2 i}^{k}
$$

for $k=1$ vector $s_{3 i}^{0}$ has values equal to zero.

At the end of each iteration, the constraint conditions are checked and if all solution values are greater than or equal to zero. If these conditions are not satisfied, the operation of maximizing the output signal follows the formula:

$$
x_{i}^{k+1}=\max \left\{0, s_{3 i}^{k}\right\} \text {. }
$$

Iterations are performed until the stop condition is satisfied. As a stop condition, it can be taken a threshold which is the difference between the received values of the output signal in subsequent iterations, e.g. 0.01 or 0.05 .

The scheme of an artificial neural network for optimization of plant production is shown in Figure 1. 


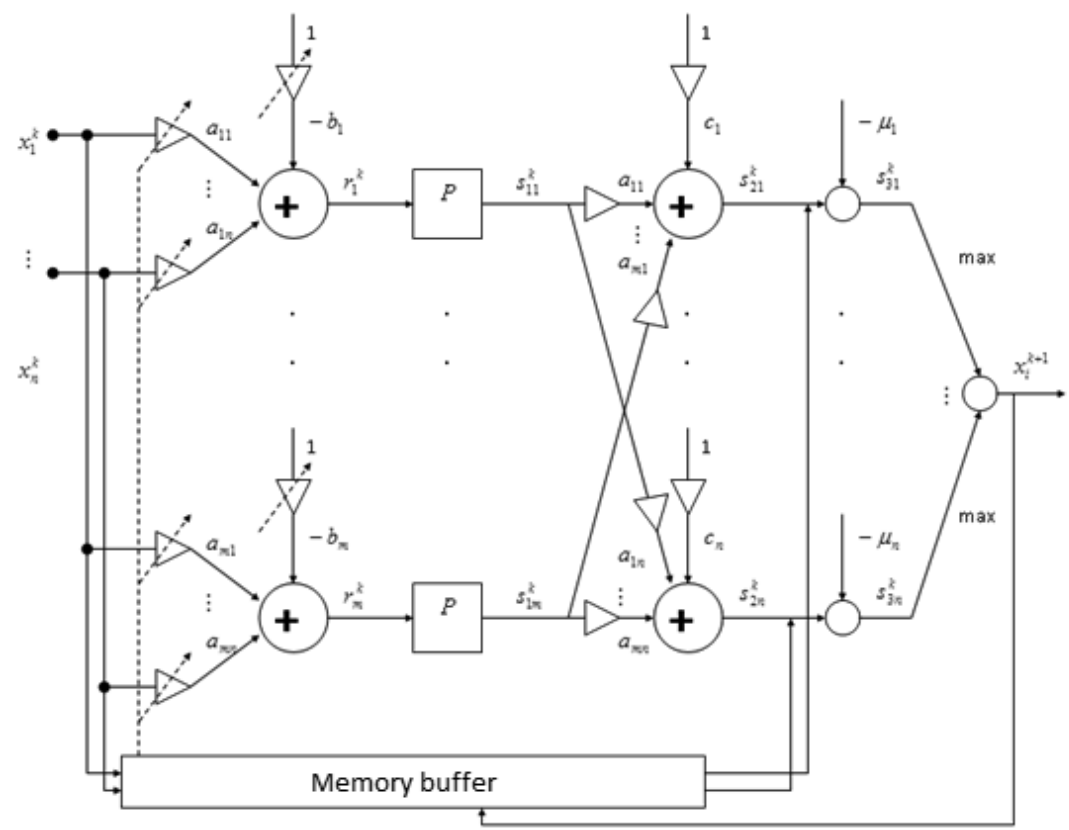

Figure 1. Model of artificial neural network for optimization of dynamic models of plant production

Source: own studies based on Kopeć (2004), p. 198.

\section{An application of artificial neural network}

In this section the obtained results of the application of ANN for optimization of the plant production are presented. Three optimization models, discussed in the previous section, were used for the calculation: serial, serial-parallel and parallel model.

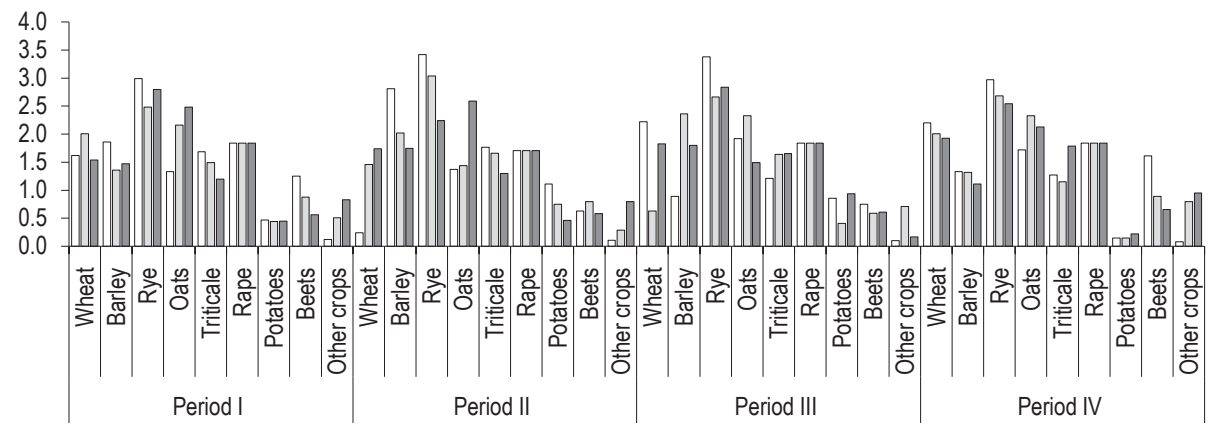

$\square$ Serial model $\quad \square$ Serial-parallel model $\quad \square$ Parallel model

Figure 2. Sowing plan obtained with serial, serial-parallel and parallel models of dynamic optimization using artificial neural network (ha)

Source: own studies. 
Figure 2 shows the sowing area of plants divided into sowing periods for serial, serial-parallel and parallel models. The results were obtained using an artificial neural network for optimization. The sowing areas for individual models differ in surface area. In each sowing period for the serial model, slight domination of one or two types of plants is visible. Rye dominates in the first period, in the second period barley and rye, whereas in the third and fourth period, wheat and rye. In the solutions for each model there are no zero sowing areas, each plant will be sown. This remark is important because in static models often the optimal sowing plan considers only one plant or several plants (not all plants are sown).

The detailed results of the optimization using the artificial neural network are presented in Table 1. The highest value of the objective function (agricultural income) was obtained for the serial model: PLN 92,269.88, for the serialparallel model, the income amounted to PLN 90,861.65, and for the parallel model PLN 90,131.32.

Comparing the income values in individual sowing periods, the largest agricultural income values in each model were obtained in the first period, and the lowest in the II period. The value of the objective function obtained for periods III and IV are comparable and equals about PLN 23,000, Table 1.

Table 1. Plant production structures obtained with artificial neural network (ha)

\begin{tabular}{|c|c|c|c|c|}
\hline Production period & Type of sowing & $\begin{array}{l}\text { Sown area } \\
\text { serial model }\end{array}$ & $\begin{array}{c}\text { Sown area } \\
\text { serial-parallel model }\end{array}$ & $\begin{array}{c}\text { Sown area } \\
\text { parallel mode }\end{array}$ \\
\hline 1 & 2 & 3 & 4 & 5 \\
\hline \multirow{9}{*}{ Period I } & wheat & 1.62 & 2.01 & 1.54 \\
\hline & barley & 1.86 & 1.36 & 1.47 \\
\hline & rye & 2.99 & 2.48 & 2.80 \\
\hline & oats & 1.33 & 2.16 & 2.48 \\
\hline & triticale & 1.69 & 1.49 & 1.20 \\
\hline & rape & 1.84 & 1.84 & 1.84 \\
\hline & potatoes & 0.47 & 0.44 & 0.45 \\
\hline & beets & 1.25 & 0.88 & 0.56 \\
\hline & other crops & 0.12 & 0.51 & 0.83 \\
\hline \multirow{9}{*}{ Period II } & wheat & 0.24 & 1.46 & 1.74 \\
\hline & barley & 2.81 & 2.02 & 1.75 \\
\hline & rye & 3.42 & 3.04 & 2.24 \\
\hline & oats & 1.37 & 1.44 & 2.59 \\
\hline & triticale & 1.77 & 1.66 & 1.30 \\
\hline & rape & 1.71 & 1.71 & 1.71 \\
\hline & potatoes & 1.11 & 0.75 & 0.46 \\
\hline & beets & 0.63 & 0.8 & 0.58 \\
\hline & other crops & 0.11 & 0.29 & 0.80 \\
\hline \multirow{9}{*}{ Period III } & wheat & 2.22 & 0.63 & 1.83 \\
\hline & barley & 0.89 & 2.36 & 1.80 \\
\hline & rye & 3.38 & 2.66 & 2.84 \\
\hline & oats & 1.92 & 2.33 & 1.49 \\
\hline & triticale & 1.21 & 1.64 & 1.65 \\
\hline & rape & 1.84 & 1.84 & 1.84 \\
\hline & potatoes & 0.86 & 0.41 & 0.94 \\
\hline & beets & 0.75 & 0.59 & 0.61 \\
\hline & other crops & 0.10 & 0.71 & 0.17 \\
\hline
\end{tabular}




\begin{tabular}{|c|c|c|c|c|}
\hline 1 & 2 & 3 & 4 & 5 \\
\hline \multirow{9}{*}{ Period IV } & wheat & 2.20 & 2.01 & 1.93 \\
\hline & barley & 1.33 & 1.32 & 1.11 \\
\hline & rye & 2.97 & 2.68 & 2.54 \\
\hline & oats & 1.72 & 2.33 & 2.13 \\
\hline & triticale & 1.27 & 1.15 & 1.79 \\
\hline & rape & 1.84 & 1.84 & 1.84 \\
\hline & potatoes & 0.15 & 0.15 & 0.22 \\
\hline & beets & 1.61 & 0.89 & 0.66 \\
\hline & other crops & 0.08 & 0.80 & 0.95 \\
\hline \multirow{4}{*}{$\begin{array}{l}\text { Agricultural } \\
\text { income (PLN) }\end{array}$} & period I & $27,054.60$ & $26,730.40$ & $25,901.22$ \\
\hline & period II & $17,644.52$ & $18,814.09$ & $18,005.01$ \\
\hline & period III & $23,748.80$ & $22,389.57$ & $23,374.87$ \\
\hline & period IV & $23,821.96$ & $22,927.59$ & $22,850.22$ \\
\hline \multicolumn{2}{|c|}{ Agricultural income (PLN) - periods I-IV } & $92,269.88$ & $90,861.65$ & $90,131.32$ \\
\hline
\end{tabular}

Source: own studies.

Analyzing the obtained solutions using the artificial neural network, it can be concluded that when optimizing plant production models, the best results were obtained for the serial model, where the value of the objective function is the highest and equals PLN 92,269.88.

\section{Conclusions}

Presented in the paper approach for optimization of production models supports production and quality management. This optimization process can be used in many areas of management where the models with objective function are considered. In this paper for optimization of the dynamic linear models of plant production the artificial neural network (ANN) was used. The ANN has found a solution for three models: serial, serial-parallel and parallel. The optimization consisted in finding the maximum value of the objective function, which was agricultural income. The best result was obtained for the serial model, where the value of agricultural income was the highest. Dynamic models of plant production with constraint conditions take into account plant changes. These constraint conditions combine particular production periods. Static models do not have this property, each production period is optimized individually without taking into account the results of the previous period. In static models, crop rotation is not taken into account and in such models solutions focus on the production of one or several plants. In dynamic models, we get a solution that guarantees correct crop rotation. It should be emphasized once again that plant rotation is an important element for obtaining high yields and maintaining soil in good condition. In solutions obtained using artificial neural network, sowing does not concentrate on one plant but is evenly distributed, each of the plants will be sown.

\section{References}

Bellman, R.E. (1957). Dynamic programming. New Jersey: Princeton University Press.

Bellman, R.E. (2003). Dynamic programming. Mineola, New York: Dover Publications.

Cacho, O., Hean, R. (2004). Dynamic optimization for evaluating externalities in agroforestry systems: An example from Australia. In: Valuing Agroforestry Systems. Advances in Agroforestry, vol. 2 (pp. 19-163). New York: Springer, Dordrecht.

Hartman, R. (1976). The harvesting decision when a standing forest has value. Economic Inquiry, 14, 52-58. 
Kennedy, J.O.S. (1986). Dynamic programming: applications to agriculture and natural resources. London: Elsevier Applied Science.

Kopeć, M. (2004). Standardowe zadanie programowania liniowego a sieć neuronowa. In: T. Trzaskalik (ed.), Metody i zastosowania badań operacyjnych '04 (pp. 193-209). Katowice: Akademia Ekonomiczna.

Landowska, A. (2017). Zastosowanie klasycznego algorytmu genetycznego do rozwiązywania dynamicznych modeli produkcji. Folia Pomeranae Universitatis Technologiae Stetinensis. Oeconomica, 337 (88) 3, 5-12.

Landowska, A., Landowski, M. (2012). Zastosowanie wybranych modeli optymalizacji dynamicznej struktury produkcji roślinnej w przeciętnym gospodarstwie rolnym. Folia Pomeranae Universitatis Technologiae Stetinensis. Oeconomica, 297 (68), $47-54$.

Leinonen, I. (1996). A Simulation Model for the Annual Frost Hardiness and Freeze Damage of Scots Pine. Annals of Botany, 78, 687-693.

Li, B.H., Yang, J.R., Dong, X.L., Li, B.D., Xu, X.M. (2007). A dynamic model forecasting infection of pear leaves by conidia of Venturia nashicola and its evaluation in unsprayed orchards. European Journal of Plant Pathology, 118 (3), 227-238.

Rutkowski, L. (2005). Metody i techniki sztucznej inteligencji. Warszawa: Wydawnictwo Naukowe PWN.

Więckowski, W. (1982). Optymalizacja plonu produkcji przedsiębiorstwa rolnego przy użyciu rozwiązań standardowych. Warszawa: PWN.

Zaród, J. (2004). Rozwiązania prymalne i dualne liniowych modeli gospodarstw rolnych województwa zachodniopomorskiego. In: T. Trzaskalik (ed.), Metody i zastosowania badań operacyjnych '04 (pp. 405-415). Katowice: Akademia Ekonomiczna.

Zaród, J. (2008). Programowanie liniowo-dynamiczne jako narzędzie analizujące zmiany w funkcjonowaniu gospodarstw rolnych. Łódź: Wydawnictwo Uniwersytetu Łódzkiego.

Zaród, J. (2010). Zastosowanie modeli programowania stochastycznego do optymalizacji struktury produkcji w gospodarstwach rolnych o różnej powierzchni. Inżynieria Rolnicza, 7 (125), 261-267.

Cite this article aS: Landowska, A. (2018). Artificial neural network for optimization of the dynamic linear model of production. European Journal of Service Management, 3 (27/2), 237-243. DOI: 10.18276/ejsm.2018.27/2-29. 